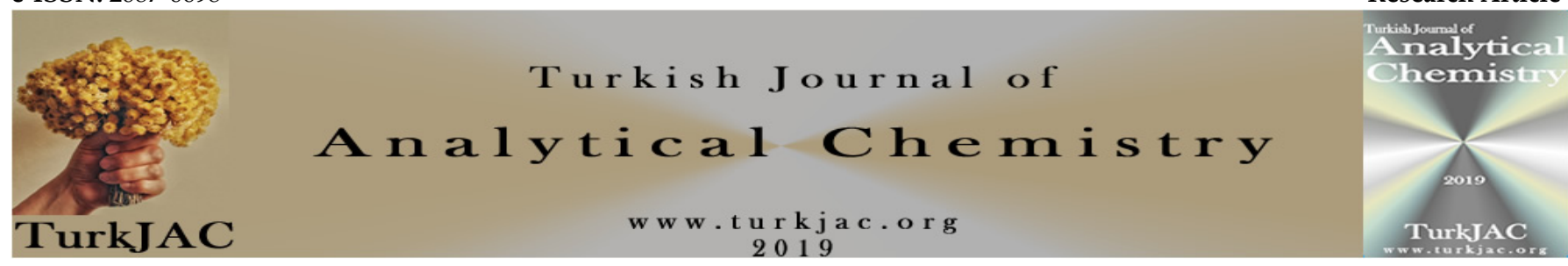

\title{
New octa-benzothiazole substituted metal-free and metallophthalocyanines: Synthesis, characterization and electrochemical studies
}

\author{
Gülsev Dilber ${ }^{1}$ (D) , Asiye Nas* (iD) , Zekeriya Biyiklioglu² (iD) \\ ${ }^{1}$ Karadeniz Technical University, Macka Vocational School, 61750, Macka, Trabzon, Turkey \\ ${ }^{2}$ Karadeniz Technical University, Faculty of Science, Department of Chemistry, 61080 Trabzon, Turkey
}

\begin{abstract}
The synthesis of novel phthalonitrile (3) and synthesis, spectroscopic and electrochemical properties of the following octa-benzothiazole substituted metal-free (4), cobalt(II) (5), and zinc(II) (6) phthalocyanines are reported for the first time in this work. The novel phthalonitrile (3) has been characterized by FT-IR, ${ }^{1} \mathrm{H}$ NMR, ${ }^{13} \mathrm{C}$ NMR, and mass spectroscopy and the novel phthalocyanines (4-6) have been characterized by FTIR, electronic spectroscopy, and mass spectroscopy. Voltammetric analysis of benzothiazole group substituted phthalocyanines (MPc) were determined by cyclic voltammetry (CV) and square wave voltammetry (SWV). According to the results, phthalocyanines revealed metal and ligand-based quasi-reversible reduction and oxidation processes. While the CoPc 5 showed one metal-based and one Pc-based reduction reactions, $\mathrm{H}_{2} \mathrm{Pc} 4$ and $\mathrm{ZnPc} 6$ gave two Pc-based reduction reactions.
\end{abstract}

Keywords: Phthalocyanine, zinc, electrochemistry, squarewave, cyclic voltammetry

\section{Introduction}

Phthalocyanines, planar aromatic macrocycles constituted by four isoindole units linked together through nitrogen atoms, were serendipitously discovered in 1928. These synthetic analogs of the naturally occurring porphyrins have been the subject of extensive research in many different fields such as lithium batteries, optical data storage, solar energy conversion, catalysis, and so on [1-6]. Apart from the use in materials science, phthalocyanines are also highly promising for their applications as magnetic resonance imaging (MRI) and photodynamic therapy (PDT) [7-9].

Many functions of metallophthalocyanine derivatives resulted from electron transfer occurring in these macromolecules. Determination of electrochemical behavior is required for the development of functional materials carrying metallophthalocyanine. MPc having $\mathrm{Pc}^{2-}$, phthalocyanine dianion, does not show redox activity at the ring. Two successive one-electron oxidations may happen by the removal of electrons from a $1 u$ forming $\mathrm{Pc}^{-1}$ and $\mathrm{Pc}^{0}$ species. Reductions happen by adding electrons to $\mathrm{e}_{8}$ to form $\mathrm{Pc}^{3-}, \mathrm{PC}^{4-}, \mathrm{Pc}^{5-}$ and $\mathrm{PC}^{6-}$ species. Each oxidation and reduction species has a definite spectrum that can be employed for its characterization. The presence of the electroactive

Citation: G. Dilber, A. Nas, Z. Biyiklioglu, New octa-benzothiazole substituted metal-free and metallophthalocyanines: synthesis, characterization and electrochemical studies, Turk J Anal Chem, 3(1), 2021, 33-38.

https://doi.org/10.51435/turkjac.935057 central metal causes additional redox processes to occur, resulting in unique electronic spectral behavior [10].

Also, phthalocyanines can be used as electrochemical sensors. The use of metallophthalocyanines as electrochemical sensors has become widespread and new sensors are being produced day by day [11,12].

In our previous papers, we reported electrochemical and spectroelectrochemical properties of various tetra substituted metal-free and metallophthalocyanines which have electroactive and non-electroactive centers. [13-16]. As seen in the literature, the electrochemical properties of tetrasubstituted metal-free and metallophthalocyanines have worked in recent years [17-19], but there is not much work on the electrochemical properties of octa-substituted metal-free and metallophthalocyanines [20-22]. So in this study, the electrochemical properties of the octa-substituted metalfree phthalocyanine (4) and zinc(II) phthalocyanine (6) having the non-electroactive center, and cobalt(II) phthalocyanine (5) carrying an electroactive center have been investigated.

*Author of correspondence: asiyenas@ktu.edu.tr

Tel: +90 46237776

Fax: +904625123552

Received: May 10, 2021

Accepted: June 04, 2021 


\section{Experimental}

The used materials and equipment were provided as supplementary information.

\subsection{Synthesis}

2.1.1. Synthesis of 4,5-bis(2-(benzo[d]thiazol-2-yl)phenoxy) phthalonitrile (3)

The mixture of 2-(benzo[d]thiazol-2-yl) phenol (1) (2.00 $\mathrm{g}$, $8.80 \mathrm{mmol}$ ) and 4,5-dichlorophthalonitrile (2) (0.86 g, $4.40 \mathrm{mmol}$ ) were dissolved in dry DMF $(30 \mathrm{ml})$ under nitrogen atmosphere and this mixture was stirred at $65^{\circ} \mathrm{C}$ for $10 \mathrm{~min}$. After stirring, finely ground anhydrous $\mathrm{K}_{2} \mathrm{CO}_{3}(2.42 \mathrm{~g}, 17.60 \mathrm{mmol})$ was added over a period of 2 $\mathrm{h}$ and it was stirred under the nitrogen atmosphere at $65{ }^{\circ} \mathrm{C}$ for 3 days. The reaction mixture was added crushed ice. The forming white precipitate was filtered off, washed with distilled water, and then dried in vacuo. Yield: $1.33 \mathrm{~g}$ (52\%), m.p.: 109.2-110.3 ${ }^{\circ} \mathrm{C}$. $\mathrm{C}_{34} \mathrm{H}_{18} \mathrm{~N}_{4} \mathrm{O}_{2} \mathrm{~S}_{2}$. FT-IR $v_{\max } / \mathrm{cm}^{-1}$ : $3061(\mathrm{Ar}-\mathrm{H}), 2237(\mathrm{C} \equiv \mathrm{N})$, 1482, 1381, 1270, 1197, 1010, 969, 757, 727, 694. ${ }^{1} \mathrm{H}$ NMR $\left(\mathrm{CDCl}_{3}\right)(\delta$ : ppm): 8.57-8.56 (d, H, Ar-H), 8.07-8.05 (d, H, Ar-H), 8.02-8.00 (d, H, Ar-H), 7.93 (s, H, Ar-H), 7.91-7.88 (m, 2H, Ar-H) 7.72-7.70 (d, H, Ar-H), 7.65-7.62 (t, H, Ar$\mathrm{H})$, 7.53-7.50 (m, 3H, Ar-H), 7.45-7.40 (m, 3H, Ar-H), 7.19$7.17(\mathrm{~d}, \mathrm{H}, \mathrm{Ar}-\mathrm{H})$, 7.14-7.12 (d, H, Ar-H), 7.09 (s, H, Ar$\mathrm{H}), 7.00-6.96(\mathrm{t}, \mathrm{H}, \mathrm{Ar}-\mathrm{H}) .{ }^{13} \mathrm{C} \mathrm{NMR}\left(\mathrm{CDCl}_{3}\right)(\delta: \mathrm{ppm})$ : $169.39,160.68,157.94,157.29,152.61,151.84,150.42$, $135.62,135.54,132.80,132.66,131.39,129.84,128.45$, $127.55,126.73,126.61,125.75,125.59,123.49,122.20$, $121.72,121.56,121.50,119.94,119.57,117.87,116.79$, 115.62, 114.28, 114.22, 110.36. MS (ES+), m/z: Calc.: 578.68; Found: $578.66[\mathrm{M}]^{+}$.

\subsubsection{Synthesis of metal-free phthalocyanine $\mathrm{H}_{2} \mathrm{Pc}$ (4)}

Compound $3(0.20 \mathrm{~g}, 0.34 \mathrm{mmol})$ and three drops of DBU were stirred in dry $n$-pentanol $(3 \mathrm{~mL})$ under reflux in a nitrogen atmosphere at $160{ }^{\circ} \mathrm{C}$ in a sealed glass tube for $24 \mathrm{~h}$. Then, the mixture was degassed several times before it was left to cool to room temperature. $20 \mathrm{~mL}$ of ethanol was added to the mixture to be precipitated the green crude product and filtered off. The obtained green product was filtered off again after the refluxing with 40 $\mathrm{mL}$ of ethanol for $4 \mathrm{~h}$. The solid product was successively washed several times with hot ethanol, distilled water, and diethyl ether to removing the organic impurities. Column chromatography using chloroform-methanol (96:4) solvent system as eluent was applied to purification of the product after it dried in vacuo. Yield: $70 \mathrm{mg}(35 \%)$, m.p.: $>300{ }^{\circ} \mathrm{C}$. $\mathrm{C}_{136} \mathrm{H}_{74} \mathrm{~N}_{16} \mathrm{O}_{8} \mathrm{~S}_{8}$. FT-IR $v_{\max } / \mathrm{cm}^{-1}: 3286(\mathrm{~N}-\mathrm{H}), 3061($ Ar-H), 1497, 1422, 1239, 1100, $1012,871,749,726$. UV/vis (chloroform): $\lambda, \mathrm{nm}(\log \varepsilon)$ : 712 (5.40), 675 (5.26), 645 (4.79), 611 (4.62), 384 (4.92). MS
(ES+), m/z: Calc.: 2316.72; Found: 1550.480 [M$\left.6 \mathrm{C}_{7} \mathrm{H}_{4} \mathrm{NS}+\mathrm{K}\right]^{+}$.

2.1.3. General procedures for metallophthalocyanine derivatives $(5,6)$

The mixture of compound $3(0.40 \mathrm{~g}, 0.68 \mathrm{mmol})$, anhydrous metal salt $\left[\mathrm{CoCl}_{2}(88 \mathrm{mg}, 0.68 \mathrm{mmol})\right.$ or $\left.\mathrm{Zn}\left(\mathrm{CH}_{3} \mathrm{COO}\right)_{2}(124 \mathrm{mg}, 0.68 \mathrm{mmol})\right]$ and three drops of 1,8-diazabicyclo[5.4.0]undec-7-ene was stirred at $160^{\circ} \mathrm{C}$ with dry $n$-pentanol $(3 \mathrm{~mL})$ in a sealed tube for $24 \mathrm{~h}$. Then, the mixture was left to cool to room temperature. The green crude product was precipitated with $10 \mathrm{~mL}$ of ethanol and then filtered off. The green-colored product was filtered off again after refluxing with $40 \mathrm{~mL}$ of ethanol for $4 \mathrm{~h}$. It was successively washed several times with hot ethanol, distilled water, and diethyl ether to remove the organic impurities. Column chromatography using a chloroform-methanol (96:4) solvent system as eluent was applied to purify the product after it dried in vacuo.

\subsubsection{Cobalt (II) phthalocyanine (5)}

Yield: $27 \mathrm{mg}(7 \%)$, m.p.: $>300{ }^{\circ} \mathrm{C} . \mathrm{C}_{136} \mathrm{H}_{72} \mathrm{~N}_{16} \mathrm{O}_{8} \mathrm{~S}_{8} \mathrm{Co}$. FTIR $v_{\max } / \mathrm{cm}^{-1}: 3058(\mathrm{Ar}-\mathrm{H}), 1497,1432,1399,1242,1195$, 1098, 1004, 967, 888, 750, 725. UV/vis (chloroform): $\lambda$, nm $(\log \varepsilon): 682$ (5.15), 613 (4.48), 305 (5.15). MS (ES+), m/z: Calc.: 2373.63; Found: 1607.901 [M-6C $\left.7 \mathrm{H}_{4} \mathrm{NS}+\mathrm{K}\right]^{+}$.

\subsubsection{Zinc (II) phthalocyanine (6)}

Yield: $102 \mathrm{mg}(25 \%)$, m.p.: $>300{ }^{\circ} \mathrm{C} . \mathrm{C}_{136} \mathrm{H}_{72} \mathrm{~N}_{16} \mathrm{O}_{8} \mathrm{~S} 8 \mathrm{Zn}$. FTIR $v_{\max } / \mathrm{cm}^{-1}$ (KBr pellet): 3061 (Ar-H), 1727, 1428, 1388, 1239, 1195, 1094, 990, 877, 753, 744. UV/vis (chloroform): $\lambda$, nm (log $\varepsilon): 691$ (5.25), 619 (4.52), 358 (4.86), 317 (5.06). MS (ES+), $m / z$ : Calc.: 2380.09; Found: 1614.725 [M$\left.6 \mathrm{C}_{7} \mathrm{H}_{4} \mathrm{NS}+\mathrm{K}\right]^{+}$.

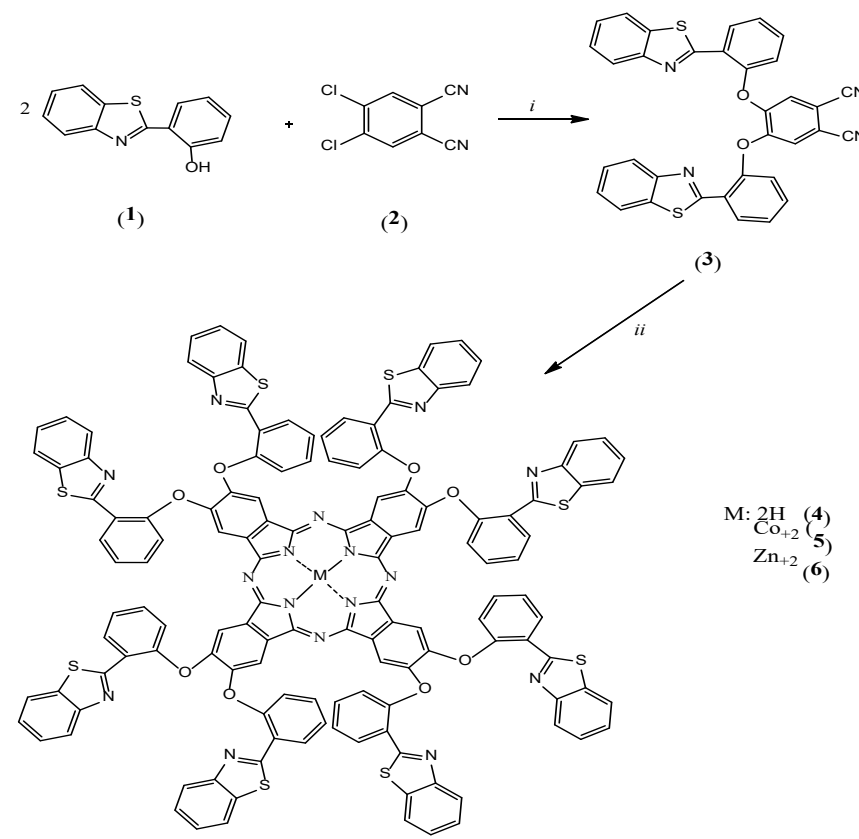

Scheme 1. Synthesis of 3, 4, 5 and 6. $i$ : $\mathrm{K}_{2} \mathrm{CO}_{3}, \mathrm{DMF}, 50{ }^{\circ} \mathrm{C}, 5$ days. $i$ : 1 pentanol, DBU, related metal salts $\left(\mathrm{CoCl}_{2}, \mathrm{Zn}(\mathrm{ac}) 2\right), 24 \mathrm{~h}, 160^{\circ} \mathrm{C}$ 


\section{Results and discussion}

\subsection{Synthesis and characterization}

The octa-benzothiazole substituted phthalonitrile derivative 3 was obtained by the reaction of 2(benzo[d]thiazol-2-yl)phenol 1 with 4,5dichlorophthalonitrile 2 in 52\% yield (Scheme 1). The nucleophilic substitution reaction was performed in the presence of anhydrous $\mathrm{K}_{2} \mathrm{CO}_{3}$ in dry DMF at $65^{\circ} \mathrm{C}$ [23].

Octa-substituted zinc(II) and cobalt(II) phthalocyanines (5 and 6) were syntheses by treatment of phthalonitrile derivatives 3 in the presence of related anhydrous metal salts $\left(\mathrm{Zn}\left(\mathrm{CH}_{3} \mathrm{COO}\right)_{2}\right.$ and $\mathrm{CoCl}_{2}$ respectively) as a metal source in dried $n$-pentanol at $160{ }^{\circ} \mathrm{C}$ [24]. The yields of the reactions for compounds 5 and 6 were determined as $7 \%$ and 25\%, respectively. Starting phthalonitrile derivatives 3, metal-free phthalocyanine compound 4 was synthesized under the same conditions without using metal salt in a $52 \%$ yield. The general synthetic procedures of the novel phthalocyanine compounds (4-6) were shown in Scheme 1. Purification of the crude products was carried out by column chromatography using the chloroformmethanol solvent system as an eluent.

The structures of novel compounds were characterized by FT-IR, ${ }^{1} \mathrm{H}$ NMR, ${ }^{13} \mathrm{C}$ NMR, UV-vis spectroscopies, and mass spectra.

For compound 3, the appearance of vibration bands at $2223 \mathrm{C} \equiv \mathrm{N}, 1283$ (Ar-O-C) in the FT-IR spectrum showed the formation of 3 . In the ${ }^{1} \mathrm{H}$ NMR spectrum of this phthalonitrile 3, the proton signal of $\mathrm{OH}$ group of 2(benzo[d]thiazol-2-yl)phenol disappeared as expected. The resonances for the compound 3 in the ${ }^{1} \mathrm{H}$ NMR were observed between 8.57-6.96 ppm integrating for a total of 18 aromatic protons. In the ${ }^{13} \mathrm{C}$ NMR spectrum of 3 , the characteristic signals of nitrile carbon atoms were observed at $\delta=11.79,115.62 \mathrm{ppm}$. The mass spectrum of phthalonitrile 3 showed a molecular ion peak at $m / z=578.66[\mathrm{M}]^{+}$.

For the new phthalocyanine compounds, cyclotetramerization of phthalonitrile 3 was evidenced by the loss of the $-\mathrm{C} \equiv \mathrm{N}$ signal in the FT-IR spectrum of compounds 4, 5, and 6 after the formation of the phthalocyanine rings. Mass spectra of phthalocyanine compounds 4, 5, and 6 reasonably supported the expected structures when observing molecular ion peaks at 1550.480 as $\left[\mathrm{M}-6 \mathrm{C}_{7} \mathrm{H}_{4} \mathrm{NS}+\mathrm{K}\right]^{+}$for $4,1607.901$ as [M$\left.6 \mathrm{C}_{7} \mathrm{H}_{4} \mathrm{NS}+\mathrm{K}\right]^{+}$for 5 and 1614.725 as $\left[\mathrm{M}-6 \mathrm{C}_{7} \mathrm{H}_{4} \mathrm{NS}+\mathrm{K}\right]^{+}$for 6 (Fig. 1, Fig. 2 and Fig. 3), respectively.

\subsection{Electronic absorption spectra}

The electronic spectra of phthalocyanines exhibit several bands which are due to $\pi-\pi^{*}$ and $n-\pi^{*}$ transitions. In the near UV region, there is the $\mathrm{B}$ band or Soret band at approximately between $300-400 \mathrm{~nm}$ and finally, there is the strongest $\mathrm{Q}$ band at approximately between 600-700 $\mathrm{nm}$. While the $\mathrm{Q}$ bands of the $\mathrm{H}_{2} \mathrm{Pcs}$ are observed as split two bands, because of $D_{2 h}$ symmetry and the lifting of the degeneracy of the LUMO (eg) level, as Qx and Qy bands that of MPcs are observed as a single intense band because of $D_{4 h}$ symmetry $[10,25]$.

Fig. 4 shows the UV-Vis absorption spectra of complexes 4-6 in chloroform. Table 1 contains a summary of the $Q$ band maxima of the complexes (4-6). In UV-vis spectra of metal-free (4) phthalocyanine gave a split two Q band absorptions at 712 and $675 \mathrm{~nm}$ with shoulders 645 and $611 \mathrm{~nm}$, respectively as expected.

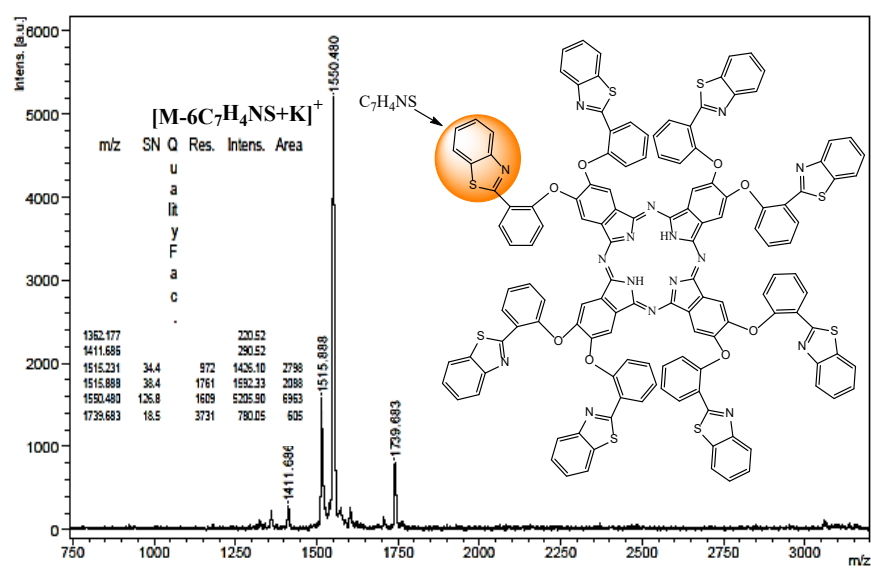

Figure 1. Mass spectrum of phthalocyanine 4

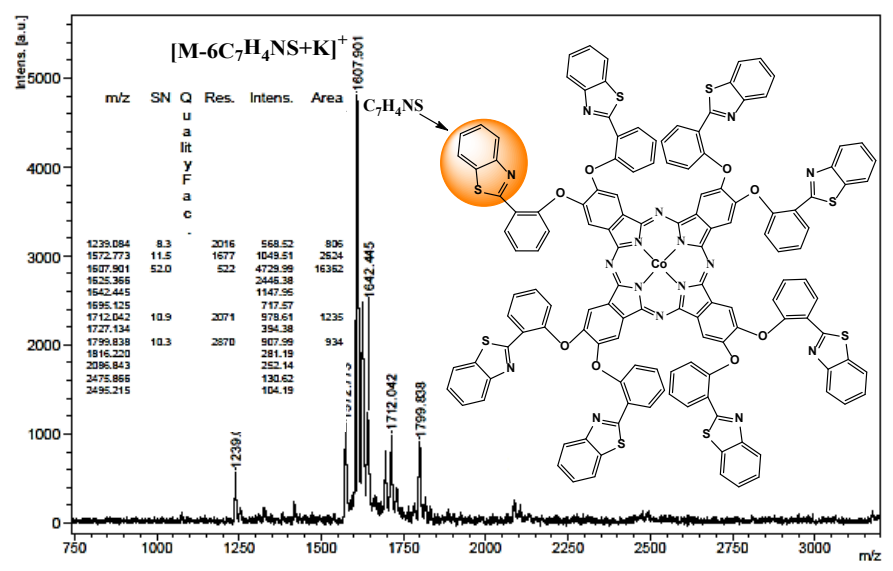

Figure 2. Mass spectrum of phthalocyanine 5

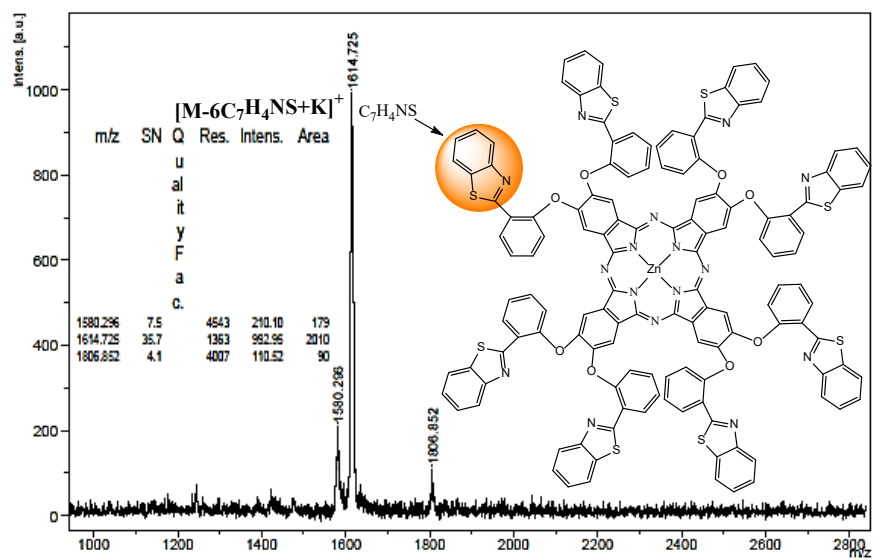

Figure 3. Mass spectrum of phthalocyanine 6 
Table 1. Absorption spectral data for 4, 5, and 6 in chloroform

\begin{tabular}{lccccc}
\hline & Solvent & $\begin{array}{c}\text { Q band, } \\
\lambda \max (\mathbf{n m})\end{array}$ & $\log \varepsilon$ & $\begin{array}{c}\text { B band, } \\
\lambda \max (\mathbf{n m})\end{array}$ & $\log \varepsilon$ \\
\hline \multirow{3}{*}{ H2Pc (4) } & Chloroform & 612 & 5.40 & & \\
& & 645 & 5.26 & 384 & 4.92 \\
& & 611 & 4.79 & & \\
CoPc (5) & Chloroform & 682 & 5.15 & & 5.15 \\
& & 613 & 4.48 & 305 & 4.86 \\
\multirow{2}{*}{ ZnPc (6) } & Chloroform & 691 & 5.25 & 358 & 5.06 \\
\hline
\end{tabular}

The cobalt(II) (5) and zinc(II) (6) phthalocyanines gave an intense single $Q$ band absorption of the $\pi-\pi^{*}$ transitions at 682 and $691 \mathrm{~nm}$ with shoulders 613 and 619 $\mathrm{nm}$, respectively. The $\mathrm{B}$ bands of complexes were observed at $384 \mathrm{~nm}$ for $4,305 \mathrm{~nm}$ for 5 , and $(358,317) \mathrm{nm}$ for 6 , respectively.

\subsection{Electrochemical Studies}

Electrochemical studies of $\mathrm{H}_{2} \mathrm{Pc}, \mathrm{ZnPc}, \mathrm{CoPc}$ were achieved in DCM using a (DCM)/(TBAP) electrolyte system on a Pt working electrode. The results are shown in Table 2. Fig. 5 shows the $\mathrm{CV}$ and the SWV of $\mathrm{H}_{2} \mathrm{Pc}_{\mathrm{C}}$ in DCM. $\mathrm{H}_{2} \mathrm{Pc}$ gave two ring-based and quasi-reversible reductions $\left(\mathrm{R}_{1}=-0.55 \mathrm{~V}, \mathrm{R}_{2}=-0.91 \mathrm{~V}\right)$ and one oxidation $\left(\mathrm{O}_{1}=1.22 \mathrm{~V}\right)$ process. This data of the $\mathrm{H}_{2} \mathrm{Pc}$ is compatible with $\mathrm{H}_{2} \mathrm{Pc}$ behavior in literature [26]. Fig. 6 shows the $\mathrm{CV}$ and the SWV of ZnPc. Similarly, ZnPc gave two ringbased and quasi-reversible reductions $\left(\mathrm{R}_{1}=-0.92 \mathrm{~V}\right.$, $\left.\mathrm{R}_{2}=-1.17 \mathrm{~V}\right)$ and one oxidation $\left(\mathrm{O}_{1}=0.93 \mathrm{~V}\right)$ process. But, CoPc showed different electrochemical behavior than $\mathrm{H}_{2} \mathrm{Pc}$ and ZnPc. Fig. 7 shows the $\mathrm{CV}$ and the SWV of CoPc. As shown in Fig. 7, CoPc gave one metal-based and one ring based quasi-reversible reductions $\left(\mathrm{R}_{1}=\right.$ $\left.0.20 \mathrm{~V}, \mathrm{R}_{2}=-1.24 \mathrm{~V}\right)$, two oxidation $\left(\mathrm{O}_{1}=0.92 \mathrm{~V}, \mathrm{O}_{2}=1.29\right.$ $\mathrm{V})$ processes.

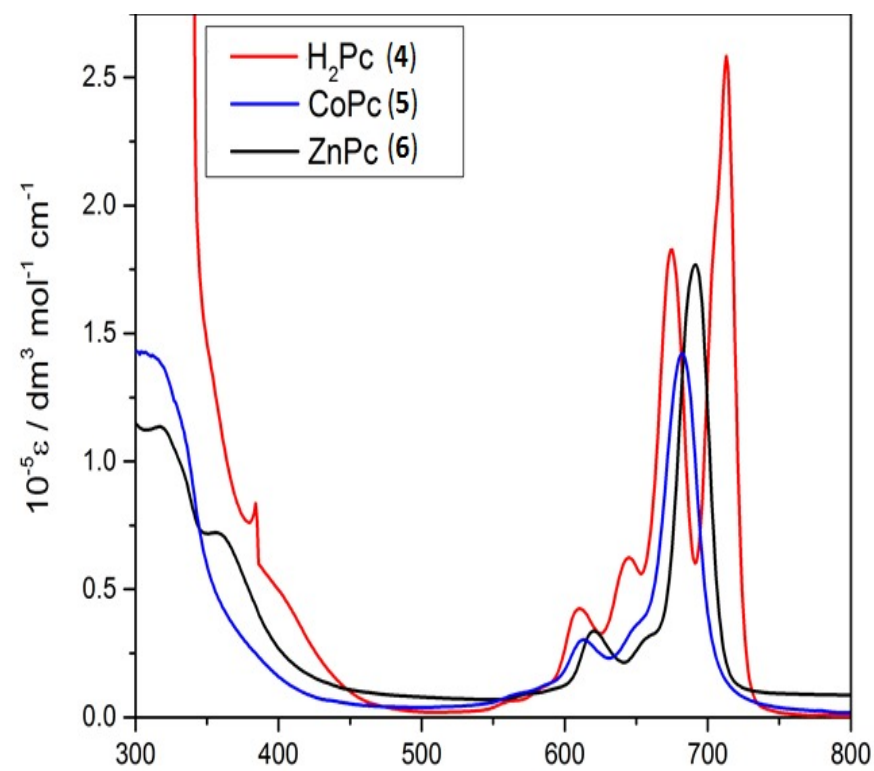

Figure 4. Absorption spectra of novel synthesized octa-substituted phthalocyanines (4-6) in chloroform
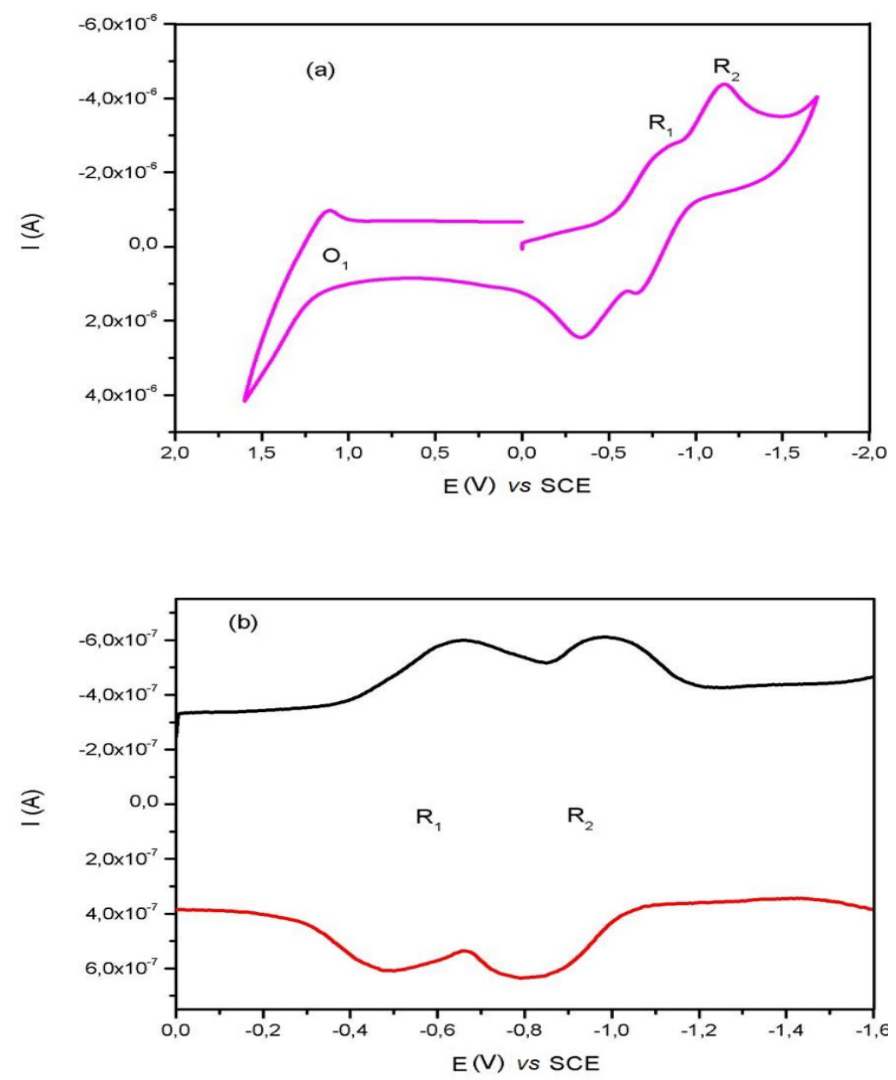

Figure 5. (a) $\mathrm{CV}$ of $\mathbf{H}_{2} \mathbf{P c}$ recorded at $0.100 \mathrm{Vs}^{-1}$ scan rate on a $\mathrm{Pt}$ electrode in DCM/TBAP. (b) SWV of $\mathbf{H}_{2} \mathbf{P c}$ recorded at $0.100 \mathrm{Vs}^{-1}$ scan rate on a $\mathrm{Pt}$ electrode in DCM/TBAP
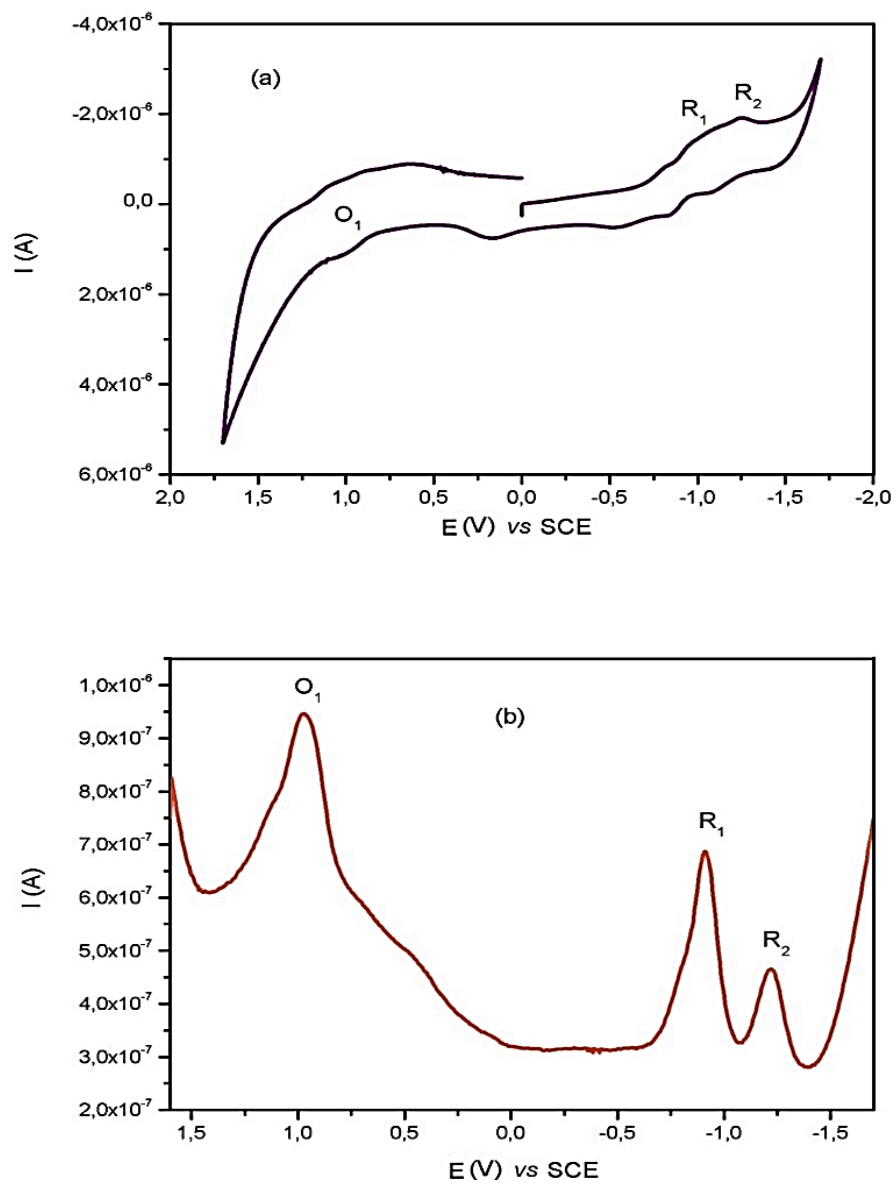

Figure 6. (a) $\mathrm{CV}$ of $\mathrm{ZnPc}$ recorded at $0.100 \mathrm{Vs}^{-1}$ scan rate on a $\mathrm{Pt}$ electrode in DCM/TBAP. (b) SWV of $\mathrm{ZnPc}$ recorded at $0.100 \mathrm{Vs}^{-1}$ scan rate on a Pt electrode in DCM/TBAP 
Table 2. Voltammetric data of the 4-6. The voltammetric data were given versus SCE

\begin{tabular}{lcccc}
\hline Phthalocyanines & Label & ${ }^{\mathrm{a}} \boldsymbol{E}_{1 / 2}$ & ${ }^{\mathrm{b}} \boldsymbol{\Delta} \boldsymbol{E}_{\mathrm{p}}(\mathbf{m V})$ & ${ }^{\mathrm{c}} \boldsymbol{\Delta} \boldsymbol{E}_{1 / 2}$ \\
\hline \multirow{3}{*}{$\mathrm{H}_{2} \mathrm{Pc}(4)$} & $\mathrm{R}_{1}$ & -0.55 & 161 & \\
& $\mathrm{R}_{2}$ & -0.91 & 156 & 1.77 \\
& $\mathrm{O}_{1}$ & 1.22 & 170 & \\
$\mathrm{ZnPc}(5)$ & $\mathrm{R}_{1}$ & -0.92 & 178 & \\
& $\mathrm{R}_{2}$ & -1.17 & 166 & 1.85 \\
& $\mathrm{O}_{1}$ & 0.93 & 180 & \\
$\mathrm{CoPc}(6)$ & $\mathrm{R}_{1}$ & -0.20 & 173 & \\
& $\mathrm{R}_{2}$ & -1.24 & 151 & \multirow{2}{*}{1.12} \\
& $\mathrm{O}_{1}$ & 0.92 & 144 & \\
\hline
\end{tabular}

a: $E_{1 / 2}$ values $\left(\left(E_{\mathrm{pa}}+E_{\mathrm{pc}}\right) / 2\right)$ were given versus $\mathrm{SCE}$ at $0.100 \mathrm{Vs}^{-1}$ scan rate. b: $\Delta E_{\mathrm{p}}=E_{\mathrm{pa}}-E_{\mathrm{pc}}$. $: \Delta E_{1 / 2}=\mathrm{E}_{1 / 2}$ (first oxidation)-E $1 / 2$ (first reduction)
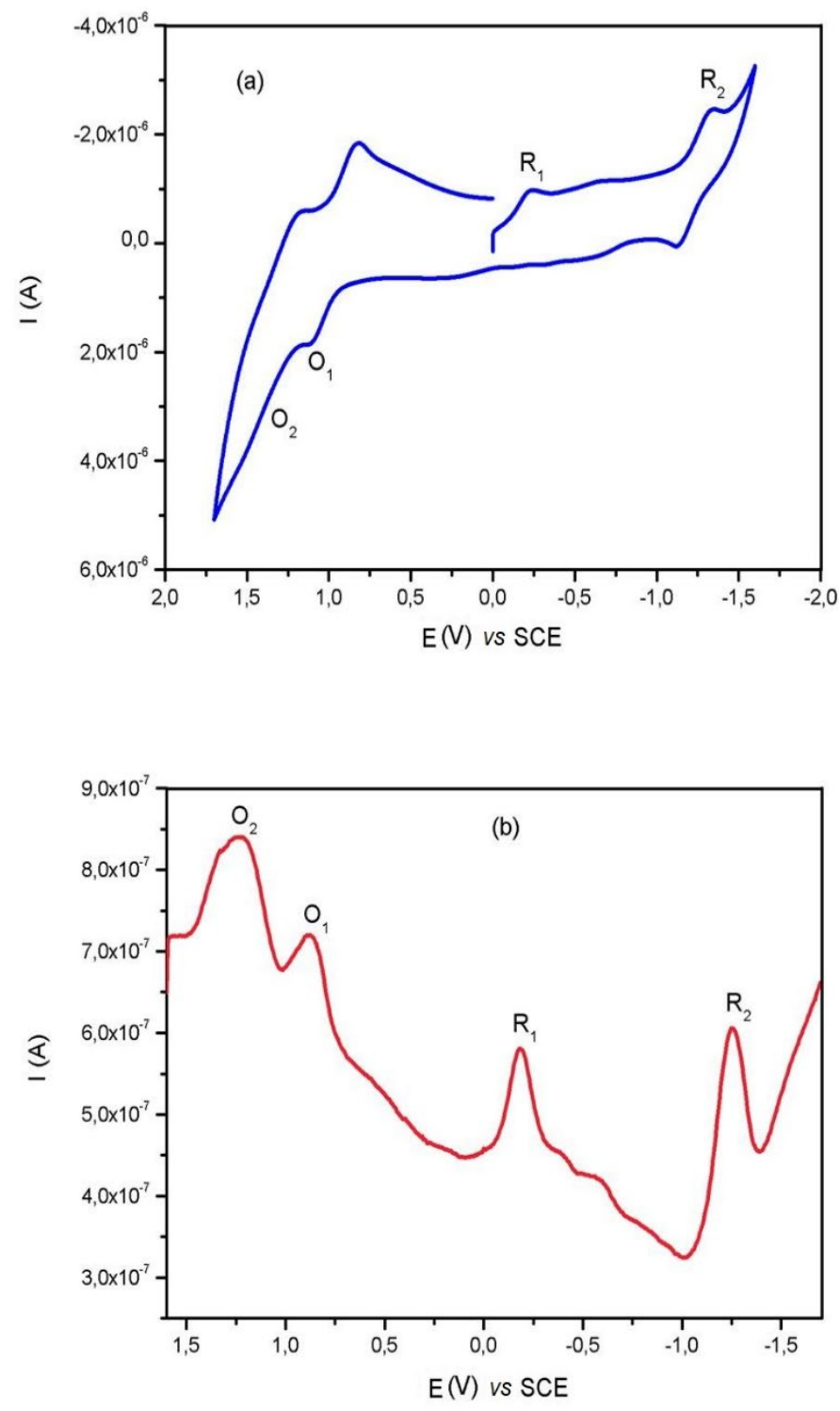

Figure 7. (a) $\mathrm{CV}$ of CoPc recorded at $0.100 \mathrm{Vs}^{-1}$ scan rate on a $\mathrm{Pt}$ electrode in DCM/TBAP. (b) SWV of CoPc recorded at $0.100 \mathrm{Vs}^{-1}$ scan rate on a Pt electrode in DCM/TBAP

\section{Conclusions}

Octa-benzothiazole substituted $\mathrm{H}_{2} \mathrm{Pc}$, $\mathrm{CoPc}$, and $\mathrm{ZnPc}$ phthalocyanines were synthesized in moderate yields and fully characterized by general spectroscopic techniques such as FT-IR, UV-Vis, ${ }^{1} \mathrm{H}-\mathrm{NMR}$, and MS. The obtained novel compounds exhibited excellent solubility in most organic solvents such as $\mathrm{CHCl}_{3}, \mathrm{CHCl}_{2}, \mathrm{THF}$, DMSO, and DMF. CV and SWV were used to determine the electrochemical properties of the $\mathrm{H}_{2} \mathrm{Pc}$, the $\mathrm{ZnPc}$, and the CoPc. Electrochemical responses of the $\mathrm{H}_{2} \mathrm{Pc}$, the $\mathrm{ZnPc}$, and the CoPc verified the proposed structure. The $\mathrm{H}_{2} \mathrm{Pc}$ and the $\mathrm{ZnPc}$ showed only ring-based redox processes. But CoPc exhibited one metal-based and one ring-based redox reactions. These properties increase their possible usage in different electrochemical applications.

\section{Acknowledgement}

This study was supported by the Research Fund of Karadeniz Technical University, Project no: FHD-20187631 (Trabzon-Turkey).

\section{References}

[1] A. Arul, M. Christy, M. Y. Oh, Y. S. Lee, K. S. Nahm, Nanofiber carbon-supported phthalocyanine metal complexes as solid electrocatalysts for lithium-air batteries, Electrochim Acta, 218, 2016, 335-344.

[2] Y. Xuan, L. Xie, X. Huang, B. Su, Molecular electrocatalysis of oxygen reduction by iron(II) phthalocyanine at the liquid/liquid interface, J Electroanal Chem, 766, 2016 37-43.

[3] H. Karaca, Redox chemistry, spectroelectrochemistry and catalytic activity of novel synthesized phthalocyanines bearing four Schiff bases on the periphery, J Organomet Chem, 822, 2016, 39-45.

[4] I. A. Tarasyuk, I. A. Kuzmin, Y. S. Marfin, A. S. Vashurin, A. A. Voronina, E. V. Rumyantsev, Synthesis and catalytic properties of hybrid materials based on organically modified silica matrix with cobalt phthalocyanine, Synthetic Met, 217, 2016, 189-196.

[5] N. Li, Z. Sun, R. Liu, L. Xu, K. Xu, X.-M. Song, Enhanced power conversion efficiency in phthalocyanine-sensitized solar cells by modifying $\mathrm{TiO}_{2}$ photoanode with polyoxometalate, Sol Energ Mat Sol C, 157, 2016, 853-860.

[6] Y. Baygu, T. Soganci, N. Kabay, Y. Gök, M. Ak, Phthalocyaninecored conductive polymer design: effect of substitution pattern and chalcogen nature on optical and electrical properties of $\mathrm{Zn}$ (II)phthalocyanine-cored polycarbazoles, Mater Today Chem, 18, 2020, 100360.

[7] A. Günsel, P. Taslimi, G. Yaşa Atmaca, A. T. Bilgiçli, H. Pişkin, Y. Ceylan, A. Erdoğmuş, M. N. Yarasir, İ. Gülçin, Novel potential metabolic enzymes inhibitor, photosensitizer and antibacterial agents based on water-soluble phthalocyanine bearing imidazole derivative, J Mol Struct, 1237, 2021,130402.

[8] B. Barut, C. Ö. Yalçın, Ü. Demirbaş, The water soluble Zn(II) and $\mathrm{Mg}(\mathrm{II})$ phthalocyanines: Synthesis, photochemical, DNA photodamage and PDT effects against A549 cells, J Photoch Photobio A, 405, 2021, 112946.

[9] B. Köksoy, M. Durmuş, M. Bulut, Potential photosensitizer candidates for PDT including 7-oxy-3-thiomethylphenyl coumarino-phthalocyanines, Inorg Chim Acta, 498, 2019, 119137.

[10] T. Nyokong, Electronic Spectral and Electrochemical Behaviour of Near Infrared Absorbing Metallophthalocyanines, Structure and Bonding: Functional Phthalocyanine Molecular Materials, Editor: J. Jianzhuang, 2010, Germany, Springer. 
[11] E. Demir, H. Silah, B. Uslu, Phthalocyanine modified electrodes in electrochemical analysis, Crit Rev Anal Chem, 2020, in press, doi:10.1080/10408347.2020.1806702.

[12] O. Inam, E. Demir, B. Uslu, Voltammetric pathways for the analysis of ophthalmic drugs, Curr Pharm Anal, 16, 2020, 367-391.

[13] Z. Biyiklioglu, O. Bekircan, Synthesis and electrochemical properties of axially disubstituted silicon phthalocyanine and peripherally tetra substituted manganese(III) phthalocyanine bearing 1,2,4-triazole substituents, Synthetic Met, 200, 2015, 148155.

[14] A. Nas, H. Kantekin, A. Koca, Novel 4-(2-(benzo[d]thiazol-2yl)phenoxy) substituted phthalocyanine derivatives: Synthesis, electrochemical and in situ spectroelectro-chemical characterization, J Organomet Chem, 757, 2014, 62-71.

[15] Z. Bıyıklıŏlu, V. Çakır, D. Çakır, H. Kantekin, Crown ethersubstituted water soluble phthalocyanines and their aggregation, electrochemical studies, J Organomet Chem, 749, 2014, 18-25.

[16] E. T. Saka, G. Sark1, H. Kantekin, A. Koca, Electrochemical, spectroelectrochemical and catalytical properties of new $\mathrm{Cu}(\mathrm{II})$ and Co(II) phthalocyanines, Synthetic Met, 214 ,2016, 82-91.

[17] E. T. Saka, R. Z. U. Kobak, H. Alp, G. Sarkı, A. Koca, H. Kantekin, Electrochemical and spectroelectrochemical properties of new metal free, nickel(II), lead(II) and zinc(II) phthalocyanines, Synthetic Met, 217, 2016, 295-303.

[18] Ö. İpsiz, H. Y. Yenilmez, K. Kaya, A. Koca, Z. A. Bayır, Carbazolesubstituted metallo-phthalocyanines: Synthesis, electrochemical, and spectroelectrochemical properties, Synthetic Met, 217, 2016, 94-101.

[19] Ü. Demirbaş, R. Z. U. Kobak, H. T. Akçay, D. Ünlüer, A. Koca, F. Çelik, H. Kantekin, Synthesis, characterization, electrochemical and spectroelectrochemical properties of novel peripherally tetra1,2,4-triazole substituted phthalocyanines, Synthetic Met, 215, 2016, 68-76.

[20] A. Koca, H. A. Dinçer, H. Çerlek, A. Gül, M. B. Koçak, Spectroelectrochemical characterization and controlled potential chronocoulometric demetallation of tetra- and octa-substituted lead phthalocyanines, Electrochim Acta, 52, 2006, 1199-1205.

[21] A. L. Uğur, A. Erdoğmuş, A. Koca, U. Avciata, Synthesis, spectroscopic, electrochemical and spectroelectrochemical properties of metal free, manganese, and cobalt phthalocyanines bearing peripherally octakis-[4-(thiophen-3-yl)-phenoxy] substituents, Polyhedron, 29, 2010, 3310-3317.

[22] H. R. P. Karaoğlu, A. Koca, M. B. Koçak, The synthesis and electrochemistry of novel, symmetrical, octasubstituted phthalocyanines, Synthetic Met, 182, 2013, 1-8.

[23] A. Nas. The photo-physicochemical properties of an octasubstituted zinc phthalocyanine containing 1,2,4-triazole moieties, J Coord Chem, 69, 2016, 1326-1336.

[24] G. Dilber, H. Altunparmak, A. Nas, H. Kantekin, M. Durmuş, The peripheral and non-peripheral 2H-benzotriazole substituted phthalocyanines: Synthesis, characterization, photophysical and photochemical studies of zinc derivatives, Spectrochim Acta A, 217, 2019, 128-140.

[25] M. J. Stillman, T. Nyokong, Phthalocyanines: Properties and Applications, Editor: C. C. Leznoff, 1989, USA, VCH Publishers.

[26] G. G. Köse, G. K. Karaoğlan, S. N. Işık, D. Akyüz, A. Koca, The synthesis, characterization, electrochemical and spectroelectrochemical properties of novel unsymmetrical phthalocyanines containing naphthoic acid and di-tertbutylphenoxy, Synthetic Met, 264, 2020, 116386. 


\section{Supplementary Information}

\section{Materials}

All solvents and reagents were dried and purified according to the known methods [1]. 4,5-dichlorophthalonitrile (2) was prepared according to the reported procedure [2]. Reagent grade chemicals and solvents were used obtained from commercial suppliers.

\section{Equipment}

Infrared and electronic spectra were recorded on a Perkin-Elmer FT-IR spectrometer and Unicam UV2-100 Shimadzu 2101 spectrophotometers using $1 \mathrm{~cm}$ path length cuvettes at room temperature, respectively. All of the reactions were carried in a standard Schlenk system under a dry nitrogen atmosphere. ${ }^{1} \mathrm{H}$ NMR and ${ }^{13} \mathrm{C}$ NMR spectra were recorded on a Varian Mercury $200 \mathrm{MHz}$ spectrometer by using $\mathrm{CDCl}_{3}$ as a solvent, and chemical shifts were reported $(\delta)$ relative to TMS as an internal standard. Mass spectra were recorded on a Brucker Microflex LT MALDI-TOF MS spectrometer (Gebze Technical University, Turkey). An electrothermal apparatus was used to determine the melting points. Column chromatography processes was carried out with silica gel 60 (particle size: 0.04-0.063 mm).

Gamry Interface 1000 potentiostat/galvanostat with a three-electrode configuration was employed for all electrochemical measurements at $25^{\circ} \mathrm{C}$. The working electrode was a Pt disc having a surface area of $0.071 \mathrm{~cm}^{2}$. A Pt wire was employed as the counter electrode and the saturated calomel electrode (SCE) was used as the reference electrode and separated from the bulk of the solution by a double bridge. Electrochemical grade tetrabutylammonium perchlorate (TBAP) in extra pure dichloromethane (DCM) was used as the supporting electrolyte at a concentration of $0.10 \mathrm{~mol} / \mathrm{dm}^{3}$.

\section{References}

[1] D. D. Perrin, W.L.F. Armarego, Purification of Laboratory Chemicals. 2nd ed. 1989, Oxford, Pergamon Press.

[2] D. Wöhrle, M. Eskes, K. Shigehara, A. Yamada, A simple synthesis of 4,5-disubstituted 1,2-dicyanobenzenes and 2,3,9,10,16,17,23,24octasubstituted phthalocyanines, Synth, 2, 1993, 194-196. 